\title{
Geochemical evidence for carbonated metasomatite as the mantle source of Cenozoic alkali basalts in western Qinling, China
}

\author{
Li-Qun Dai, Fei Zheng, Zi-Fu Zhao, Yong-Fei Zheng \\ University of Science and Technology of China, Hefei, China,lqdai@ustc.edu.cn
}

\section{Introduction}

Mantle peridotite was considered as the source lithology of alkali basalts. However, experimental petrology indicates that partial melting of peridotite produces different basaltic melts from natural alkali basalts in some major elements. For example, the experimental products show significantly lower $\mathrm{CaO}$ and higher $\mathrm{Al}_{2} \mathrm{O}_{3}$ contents than natural alkali basalts (e.g., Hirschmann et al., 2003; Dasgupta et al., 2007). Instead of the normal peridotite, three major metasomatic lithologies such as carbonated peridotite, pyroxenite and hornblendite have been suggested as the mantle source of alkali basalts (e.g., Hirschmann et al., 2003; Dasgupta et al., 2007; Pilet et al., 2008). Nevertheless, experimentally produced basaltic melts from these metasomatic lithologies also fail to match all the features of natural alkali basalts. The mantle lithology for alkali basalts still remains enigmatic. In addition, the origin of these metasomatic lithologies for alkali basalts also remains controversial.

During the subduction of oceanic crust, the recycling of carbonate-bearing sediment at convergent plate margins has played an important role in carbonatitic metasomatism and possible global carbon cycling. In particular, carbonated peridotite has received increasing attention due to its petrogenetic link to alkali basalts. Alkali basalts above ancient subduction zones provide us with an excellent opportunity to investigate the recycling of the subducted crustal materials, and the petrogenesis of alkali basalts. In this study, a combined study of whole-rock major-trace elements and Sr-Nd-Hf isotopes was carried out for Cenozoic alkali basalts in western Qinling orogen of China, which are associated with carbonatite. The results provide insights not only into the slab-mantle interaction in the ancient subduction zone, but also into the mantle lithology for the alkali basalts.

\section{Geochemical results}

Alkali basalts from Qinling orogen are all silica-undersaturated alkali basalts. They have low contents of $\mathrm{SiO}_{2}$ (36.9-40.8 wt.\%) and $\mathrm{Al}_{2} \mathrm{O}_{3}$ (7.3-10.2 wt.\%) but high $\mathrm{CaO}$ (13.5-14.5 wt.\%), with high $\mathrm{CaO} / \mathrm{Al}_{2} \mathrm{O}_{3}$ ratios of 1.42 to 2.19 . In the chondrite-normalized REE diagram (Fig. 1a), all the basalts show enrichment in LREE with $(\mathrm{La} / \mathrm{Yb})_{\mathrm{N}}$ ratios of 37.9 to 53.0, and without profound Eu anomalies. In the primitive mantle-normalized spidergram (Fig. 1b), they exhibit enrichment in $\mathrm{Ba}, \mathrm{Nb}$ and $\mathrm{Ta}$ but depletion in $\mathrm{Rb}, \mathrm{K}, \mathrm{Pb}, \mathrm{Zr}$ and $\mathrm{Hf}$, resembling mafic melts derived from partial melting of hornblendite and hornblendite + peridotite to some extent (Pilet, et al., 2008). The significant depletion in $\mathrm{Rb}, \mathrm{K}, \mathrm{Pb}$, $\mathrm{Zr}$, Hf and $\mathrm{Ti}$ is similar to the trace element patterns of oceanic and continental carbonatites derived from partial melting of carbonated mantle sources. The alkali basalts show low whole-rock $\left({ }^{87} \mathrm{Sr} /{ }^{86} \mathrm{Sr}\right)_{\mathrm{i}}$ ratios of 0.7041 to 0.7060 , and positive $\varepsilon_{\mathrm{Nd}}(\mathrm{t})$ values of 3.4 to 4.2 and $\varepsilon_{\mathrm{Hf}}(\mathrm{t})$ values of 5.8 to 7.2.

\section{Discussion}

For the study of basalt petrogenesis, field and petrographic observations must be combined with majortrace element and stable-radiogenic isotope compositions to make an integrated interpretation. The studied alkali basalts are associated with carbonatite lava in the field. Carbonate globules and irregular patches are also observed under a microscope. These features suggest the role of a carbonated mantle source in generating the West Qinling alkali basalts. For major elements, the alkali basalts exhibit low $\mathrm{SiO}_{2}$, but high $\mathrm{MgO}$ and $\mathrm{CaO}$ with high $\mathrm{CaO} / \mathrm{Al}_{2} \mathrm{O}_{3}$ ratios, requiring their derivation from partial melting of fertile ultramafic rocks. For trace elements, the alkali basalts are enriched in incompatible elements such as LREE, Ba and $\mathrm{Sr}$, but depleted in Rb, K, Zr, Hf, and Ti. Such trace element features are significantly different from normal MORB, but similar to carbonatite to some extent (Figs. 1a and 1b). 
Thus, these features probably indicate the involvement of carbonate-bearing crustal material in their source region. For radiogenic isotope compositions, they generally exhibit low $\left({ }^{87} \mathrm{Sr} /{ }^{86} \mathrm{Sr}\right)_{i}$ ratios, and positive $\varepsilon_{\mathrm{Nd}}(\mathrm{t})$ and $\varepsilon_{\mathrm{Hf}}(\mathrm{t})$ values, suggesting contribution from juvenile crustal components. Taken together, all these geochemical features indicate that the alkali basalts would be originated from a kind of ultramafic lithologies, which is fertile in lithochemistry, enriched in carbonate composition and meltmobile incompatible trace elements, but depleted in radiogenic isotopes.
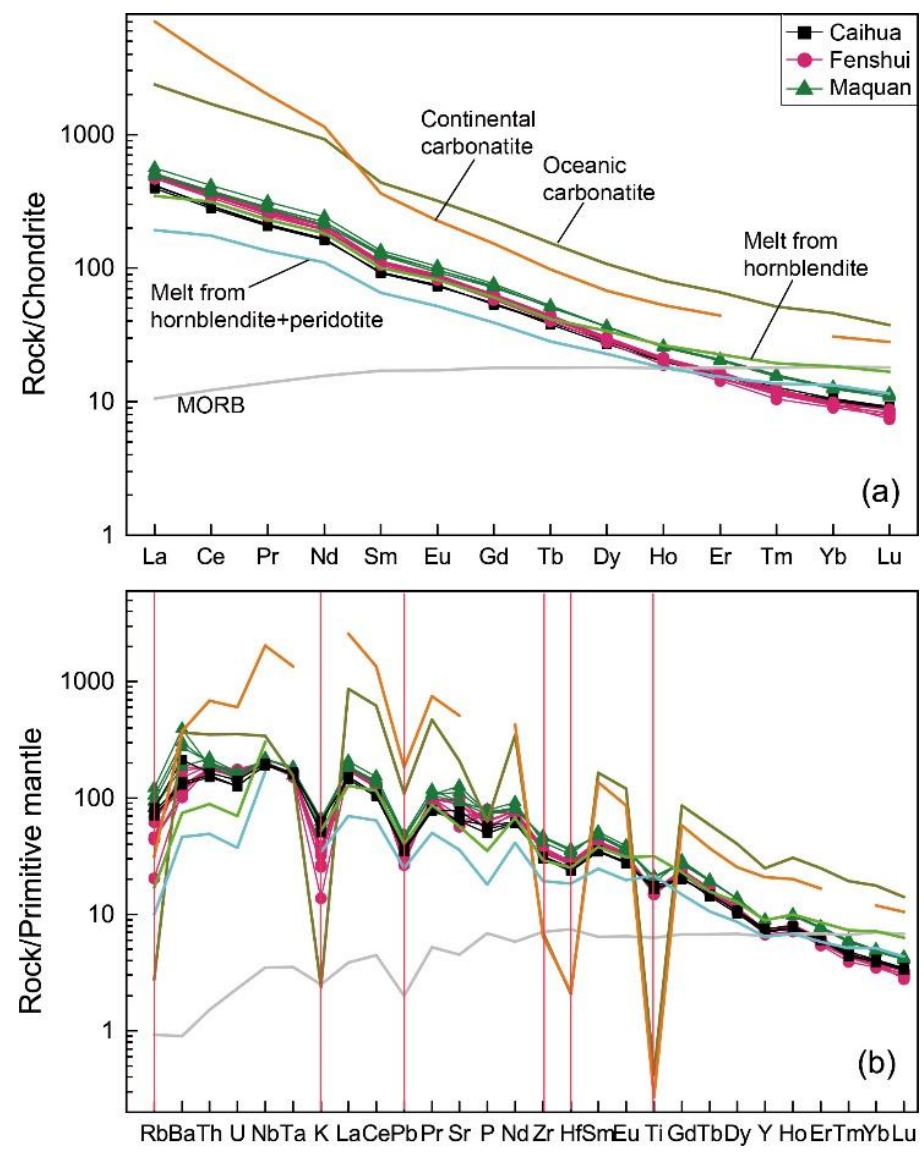

Figure 1: Chondrite-normalized REE patterns (a) and primitive mantle-normalized trace element distribution patterns (b) for alkali basalts from West Qinling. Also compared are the average oceanic and continental carbonatites compositions (Hoernle et al., 2002; Bizimis et al., 2003); melts from hornblendite and hornblendite + peridotite (Pilet et al., 2008).

Because carbonatitic metasomatism would increase the $(\mathrm{La} / \mathrm{Yb})_{\mathrm{N}}$ ratios of mantle sources and leads to strong depletion in high field strength elements (Coltorti et al., 1999). (La/Yb) $)_{\mathrm{N}}$ together with Ti/Eu ratios can be taken as useful indicators of carbonatitic metasomatism. As shown in Fig. 2a, the West Qinling alkali basalts show significantly higher $(\mathrm{La} / \mathrm{Yb})_{\mathrm{N}}$ ratios and lower Ti/Eu ratios than normal MORB, suggesting the carbonatitic metasomatism of their source region. The carbonatitic metasomatism also increases the $\mathrm{CaO}$ contents and $\mathrm{CaO} / \mathrm{Al}_{2} \mathrm{O}_{3}$ ratios of mantle peridotite, and thus those of its derived basaltic magma. The high $\mathrm{CaO} / \mathrm{Al}_{2} \mathrm{O}_{3}$ ratios, and the positive correlation between $\mathrm{CaO} / \mathrm{Al}_{2} \mathrm{O}_{3}$ and $(\mathrm{La} / \mathrm{Yb})_{\mathrm{N}}$ ratios (Fig. 2b), also suggest significant contribution of carbonatitic component to their origin.

The carbonate melts are also characterized by high $\mathrm{Zr} / \mathrm{Hf}, \mathrm{Nb} / \mathrm{Ta}$ and $\mathrm{Ce} / \mathrm{Pb}$ ratios, but low $\mathrm{Hf} / \mathrm{Sm}$ ratios. As illustrated in Figs. 2c-2f, the West Qinling alkali basalts show significantly higher $\mathrm{Zr} / \mathrm{Hf}, \mathrm{Ce} / \mathrm{Pb}$ and $\mathrm{Nb} / \mathrm{Ta}$ ratios but lower $\mathrm{Hf} / \mathrm{Sm}$ ratios than normal MORB, and plot toward the average oceanic and continental carbonatites (Hoernle et al., 2002; Bizimis et al., 2003). There are also correlations between $(\mathrm{La} / \mathrm{Yb})_{\mathrm{N}}$ versus $\mathrm{Zr} / \mathrm{Hf}$ and $\mathrm{Ce} / \mathrm{Pb}$ ratios, and $\mathrm{CaO} / \mathrm{Al}_{2} \mathrm{O}_{3}$ versus $\mathrm{Hf} / \mathrm{Sm}$ and $\mathrm{Nb} / \mathrm{Ta}$ ratios. These features suggest that the alkali basalts record the carbonatitic metasomatism. 

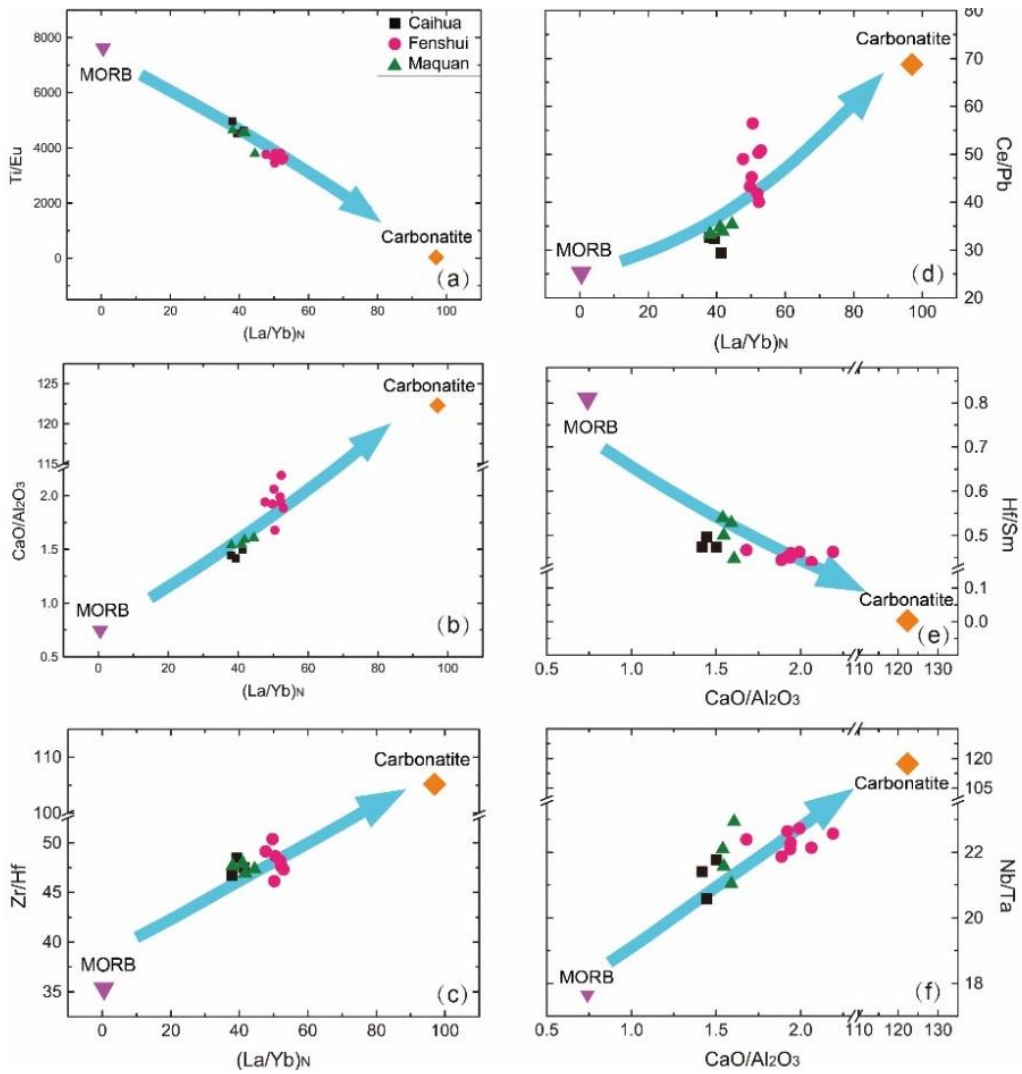

Figure 2: Plots of ( $\mathrm{La} / \mathrm{Yb}) \mathrm{N}$ versus $\mathrm{Ti} / \mathrm{Eu}(\mathrm{a}), \mathrm{CaO} / \mathrm{Al} 2 \mathrm{O} 3$ (b), $\mathrm{Zr} / \mathrm{Hf}$ (c) and $\mathrm{Ce} / \mathrm{Pb}$ ratios (d) ratios, as well as $\mathrm{CaO} / \mathrm{Al} 2 \mathrm{O} 3$ versus $\mathrm{Hf} / \mathrm{Sm}$ (e) and $\mathrm{Nb} / \mathrm{Ta}$ ratios (f) for alkali basalts from West Qinling, showing carbonatitic metasomatism.

In summary, the West Qinling alkali basalts were originated from carbonated mantle source. A comparison of major-trace elements in the basalts with some representative mantle melts confirms that their mantle lithologies are composed of the carbonated peridotite and hornblendite. Such ultramafic metasomatites would be generated by reaction of the depleted mantle peridotite with anatectic melts, locally rich or poor in carbonate, that originated from the Palaeotethyan oceanic crust in a subduction channel. As carbonation significantly depresses the solidus of mantle lithology, these ultramafic metasomatites are more susceptible to partial melting for the production of alkali basalts.

\section{References}

Bizimis, M., Salters, V.J.M., Dawson, J.B., 2003. The brevity of carbonatite sources in the mantle: evidence from Hf isotopes. Contributions to Mineralogy and Petrology 145, 281-300.

Coltorti, M., Bonadiman, C., Hinton, R.W., Siena, F., Upton, B.G.J., 1999. Carbonatite metasomatism of the oceanic upper mantle: evidence from clinopyroxenes and glasses in ultramafic xenoliths of Grande Comore, Indian Ocean. Journal of Petrology 40, 133-165.

Dasgupta, R., and Hirschmann, M. M., 2010. The deep carbon cycle and melting in Earth's interior. Earth and Planetary Science Letters 298, 1-13.

Hirschmann, M.M., Kogiso, T., Baker, M.B. and Stolper, E.M., 2003. Alkalic magmas generated by partial melting of garnet pyroxenite. Geology 31, 481-484.

Hoernle, K., Tilton, G., Le Bas,M.J., Duggen, S., Garbe-Schonberg, D., 2002. Geochemistry of oceanic carbonatites compared with continental carbonatites: mantle recycling of oceanic crustal carbonate. Contributions to Mineralogy and Petrology 142, 520-542.

Pilet, S., Baker, M.B. and Stolper, E.M., 2008. Metasomatized lithosphere and the origin of alkaline lavas. Science 320, 916-919. 